\title{
Comparative Analysis of Cement and Lateralite on the Engineering Properties of Niger Delta Soils for Pavement Construction
}

\author{
F. M. Alayaki ${ }^{1 *}$, A. Al-Tabbaa ${ }^{1}$, E. A. Meshida ${ }^{2}$ and M. J. Ayotamuno ${ }^{3}$ \\ ${ }^{1}$ Department of Engineering, CB2 1PZ, University of Cambridge, United Kingdom. \\ ${ }^{2}$ Department of Civil Engineering, Afe Babalola University, Ado Ekiti, Nigeria. \\ ${ }^{3}$ Faculty of Engineering, Rivers State University of Science and Technology, Nigeria.
}

Authors' contributions

This work was carried out in collaboration between all authors. Author FMA designed the study, performed the laboratory analyses of the engineering properties, interpreted the results, wrote the first draft of the manuscript and managed the literature searches. Authors AA, EAM, and MJA managed the analyses and literature searches. All authors read and approved the final manuscript.

Article Information

DOI: $10.9734 / B J A S T / 2015 / 18256$ Editor(s):

(1) Rares Halbac-Cotoara-Zamfir, Hydrotechnical Engineering Department, "Politehnica" University of Timisoara, Romania. Reviewers:

(1) Danupon Tonnayopas, Mining and Materials Engineering Department, Prince of Songkla University, Thailand. (2) Nur Izzi Md. Yusoff, Dept. of Civil and Structural Eng, Universiti Kebangsaan Malaysa, Malaysia.

(3) Randa M. Osman, Chemical Engineering and Pilot Plant Department, National Research Center, Cairo, Egypt. Complete Peer review History: http://www.sciencedomain.org/review-history.php?iid=1137\&id=5\&aid=9224

Original Research Article

Received 11 ${ }^{\text {th }}$ April 2015

Accepted $1^{\text {st }}$ May 2015

Published 13 ${ }^{\text {th }}$ May 2015

\section{ABSTRACT}

This study investigated the effect of cement and lateralite in improving some engineering properties of Niger Delta soils, classified as clayey soil, silty/clayey sand, and fine sand. Cement had very good effect in reducing the plasticity of the clayey soil and the silty/clayey sand but increased the plasticity of the fine sand, and all the samples had increased soaked CBR and UCS at 28 days especially with $6 \%$ and $8 \%$ cement contents. $14 \%$ lateralite content had the best effect on the silty/clayey sand in reducing the plasticity and increasing both the CBR and UCS. However, no positive effect on the plasticity indices was noticed for the clayey soil and the fine sand, but appreciable increases in their unsoaked and soaked CBR and UCS at 28 days curing. The applications of cement $(6 \%$ and $8 \%)$ and $14 \%$ lateralite would make the stabilized soils applicable as sub-base and base materials. 
Keywords: Cement; lateralite; engineering properties; CBR; UCS.

\section{INTRODUCTION}

The use of ordinary Portland cement as a soil binder is widely practiced in the construction industry for different soil types, ranging from inorganic fine-grained soils, silty / clayey soils, and organic peaty soils to soils even with low $\mathrm{pH}$, and has been proved to be a potent binder preferably for soils with minimum problematic contents. However, there have been considerable agitations in recent times to look for alternate soil binders which can serve as part or total replacement of cement because of different post-construction deficiencies that usually occur with its use. One deficiency that is of concern to road engineers is the instability of cement stabilized soil in water, especially soils containing high organic, clay and/or silt contents. In overcoming this defect, sufficiently high quantity of cement is usually used, making its application uneconomical in many constructions.

[1-3] reviewed different binders that can be used in ground improvement and noted that cement is best suited to stabilize inorganic soils than organic and clayey soils. The problematic nature of organic and clayey soils affects the hydration process required for the chemical reaction in cement-soil mixture. Also noted is the environmental impact in the production and use of cement in terms of carbon-dioxide emission, which is a cause for concern. In mitigating its use, there are intensive researches into alternate binders which are more environmental friendly. Furthermore, [1] reported that some of the new binders that are being used as full or partial replacement of cement are Ground Granulated Blastfurnace Slag (GGBS), Pulverised Fuel Ash (PFA), and Magnesium Oxide (MgO). Also reported is the use of different forms of lime which are specifically used in treating finegrained soils (clayey gravel and clays) and in conjunction with many other binders. The addition of lime to clayey soils initiates several reactions that produce both immediate and longterm changes in the soil, although the time-scale of the reaction is unknown.

\subsection{Use of Cement Stabilization in the Niger Delta}

[4] Recommended the blending of the clay soil with fine-grained sand in ratio $1: 1$ and then stabilize with cement. However high strength reduction of about $40 \%$ was noted when the stabilized mixture was soaked in water even with as much as $10 \%$ cement, thus suggested the protection of the pavement from water ingress. [5] Noted that there was significant improvement in the shear strength when $8 \%$ cement was used to stabilize the Ajali sandstone soils: soaked CBR value in excess of $100 \%$ was obtained.

[6] Used "geosta" in conjunction with cement to stabilize a soft and extremely compressible organic marine mud found within the saline mangrove swamp of Niger Delta. He discovered that there was some improvement in the strength of the soil with addition of about $1.5 \%$ geosta and $4 \%$ cement, which gave an unsoaked CBR of about 29\%: adequate enough as sub-base material. However, the use of unsoaked CBR did not represent true environmental condition (waterlogged) of the area.

[7] in their study of soils from various parts of Port Harcourt, also observed significantly improved soaked CBR value when the soils which were the residue of tertiary sedimentary rocks, were stabilized with cement-sand composed of $6 \%$ cement and $40 \%$ sand respectively. The researchers recommended that the mixture be used as sub-base material and suggested that cement-sand admixture may be technically and economically viable for road base course.

[8] in their stabilization of expansive soils collected from Rivers, Bayelsa, and Delta States, first reduced the swelling by using slake-lime and Calcium Chloride $\left(\mathrm{CaCl}_{2}\right)$ independently and then added cement to improve the strength. $10.7 \%$ of slake-lime and $6 \%$ of $\mathrm{CaCl}_{2}$ were found adequate to achieve non-swelling soil condition of $2.5 \%$ maximum free swell as postulated by [9] and $\mathrm{CaCl}_{2}$ was considered more technically and economically viable. The soaked $\mathrm{CBR}$ of $\mathrm{CaCl}_{2}-$ cement stabilized soils improved considerably in excess of $90 \%$ and the $80 \%$ soaked CBR required by [10] for use as stabilized base-course was achieved though at a high cement content of $14.6 \%$. Approximate values were obtained for all the samples used in this study, irrespective of their locations and fine-grain contents.

[11] in stabilizing laterite soils derived from shale which is particularly notorious for high clay content and lack of coarse aggregate revealed that there was appreciable improvement in the gradation of the soil when sand was added and increase in the strength with the addition of cement. The authors gave different scenarios of 
achieving economically improved laterite soils at West African Standard (WAS) and Standard Proctor (SP) compaction levels. They discovered that WAS compaction gave better results for the laterite soils than SP compaction and that effective and economic stabilization was achieved at $45 \%$ sand and $3-6 \%$ cement contents, with high resistance to loss of strength.

\subsection{Lateralite-Soil Stabilization}

Lateralite was invented by the third author and had been used to stabilize several samples of fine-grained Coastal Plain Sands and black cotton soils [12,13]. Significant increase in strength and resistivity to destabilizing impact of water were observed, even when soaked for several years. Some samples are still in water to date and none is yet to show any deteriorating signs. This revealed that this stabilizing flux has good potential in the soil treatment for use in waterlogged areas. In their studies, addition of $10 \%$ lateralite content to the weight of soil were observed to be adequate to stabilize the soils; the plasticity of the soil was reduced significantly, while the soaked CBR of the treated soil was increased to over $100 \%$ with zero free swell value. Lateralite is a flux of different mineral compositions which were selected in definite proportions and the pozzolanic reaction was effected by grinding the flux to the fineness of cement.

\section{STUDY AREA}

Disturbed soil samples were obtained from the subgrade level and the borrow-pit along East/West-Nyokuru link roads in Port-Harcourt and designated as samples 1 and 2 respectively, while disturbed sample 3 was taken from the subgrade level of Kaa-Ataba link road in Ogoni land, all in Rivers State. Sites 1 and 2 were relatively flat and free draining while site 3 was swampy with water table almost at the ground surface. There was no form of stabilization of the subgrade soils on these sites, instead the problematic soils were excavated and massive filling to formation level were done using sands dredged from nearby rivers or borrow-pit.

\section{EXPERIMENTAL DESIGN}

\subsection{Analysis of Binders Properties}

The specific gravity of the binders were determined by using the $50 \mathrm{ml}$ density bottle in accordance with [14], $\mathrm{pH}$ meter was used to determine the alkalinity of the binders after calibrations using the $\mathrm{pH} 4,7$, and 10 buffer solutions, while the setting times of the binders were determined by using manually operated vicat needle based on the test method in [15].

The oxides content of lateralite were determined using the X-ray fluorescence Spectro Xepos and USEPA 6200 test method. The spectrometer was first calibrated and the correlation coefficient for the standard curve was 0.990 . Then about $5 \mathrm{~g}$ of the milled sample ( $~ 5 \mu \mathrm{m}$ grain size) was used for the analysis. The test was done at the laboratory of FUGRO Nigeria Limited, Port Harcourt, Nigeria.

\subsection{Analysis of Soil Properties}

Bulk samples were air-dried at room temperature and the following tests were carried out both on the natural and stabilized soil: classification, specific gravity, compaction, California Bearing Ratio (CBR) and Unconfined Compression Strength (UCS). All tests done on the natural soil were in accordance with [14], while the procedure in [16] was used for the soil stabilization.

The Casagrande apparatus was used to determine the liquid limit on soil passing sieve $425 \mu \mathrm{m}$ and it was taken at 25 blows on the semi-logarithm graphs. $50 \mathrm{ml}$ density bottle was used to determine the specific gravity of the natural soils. West African Compaction was performed to obtain the Optimum Moisture Content (OMC) and Maximum Dry Density (MDD), this was done using the CBR mould and $4.5 \mathrm{~kg}$ rammer applied on 5 layers of the soil at 25 blows per layer. The CBR test was done both on the unsoaked and 24 hours soaked samples. While the UCS test was done using the split mould of $100 \mathrm{~mm}$ diameter $\times 200 \mathrm{~mm}$ height and tested after 7, 14 and 28 days curing. $2 \%, 4 \%$, $6 \%$ and $8 \%$ cement contents by dry weight of the soil were added for stabilization, while $14 \%$ lateralite content also by dry weight was used at the recommendation of the inventor.

\section{RESULTS AND DISCUSSION}

\subsection{Comparison of Lateralite and Cement}

Cement colour is grey, while lateralite is dark grey pulverized to very fine texture like cement (Fig.1). Lateralite had a Specific Gravity (SG) of 2.44, while cement SG was 3.02 which connoted that lateralite is less dense than cement. Lateralite had its initial setting at 45 mins and the final setting took a long time to occur (greater 
than the specified limit of 375 mins). The initial setting time of cement occurred at 105 mins and the final setting time took place within 4 hours of the start of the test. Both binders are alkali. One of the generic features of cement is that the ratio of calcium oxide $(\mathrm{CaO})$ to silicon oxide $\left(\mathrm{SiO}_{2}\right)$ must not be less than 2.0 as recommended in [17], lateralite however had $\mathrm{CaO}$ and $\mathrm{SiO}_{2}$ ratio of 1.3. Also, both iron and aluminum oxides of lateralite were slightly higher than the highest specified limit of cement while its calcium oxide is about $50 \%$ less than the lowest specified limit of cement, an indication that lateralite might not have the cementing capability of cement. However, silicon and magnesium oxides of lateralite were within specified as for cement as shown in Table 1.

Table 1. Results of chemical analysis

\begin{tabular}{lll}
\hline & ${ }^{*}$ Lateralite & ${ }^{* *}$ Cement \\
\hline Specific gravity & 2.44 & 3.02 \\
Initial setting time & $>300$ mins & 120 mins \\
Final setting time & $>375$ mins & 240 mins \\
$\mathrm{pH} \mathrm{@} \mathrm{23.5} 5^{\circ} \mathrm{C}$ & 12.2 & $12-13$ \\
$\mathrm{SiO}_{2}(\%)$ & 23.2 & $18.6-23.4$ \\
$\mathrm{Fe}_{2} \mathrm{O}_{3}(\%)$ & 6.70 & $1.3-6.1$ \\
$\mathrm{Al}_{2} \mathrm{O}_{3}(\%)$ & 6.67 & $2.4-6.3$ \\
$\mathrm{CaO}(\%)$ & 30.8 & $60.2-66.3$ \\
$\mathrm{MgO}(\%)$ & 3.67 & $0.6-4.8$ \\
$\mathrm{TiO}_{2}$ & 0.55 & - \\
\hline \multicolumn{3}{c}{${ }^{*} p H$ and oxides contents analyzed at FUGRO } \\
laboratory; ${ }^{* *}$ Typical pH and oxides compositions of \\
\multicolumn{3}{r}{ Portland cement (after [18]) }
\end{tabular}

\subsection{Classification of Samples}

The particle size analysis showed that all the soil samples were fine grained devoid of medium and

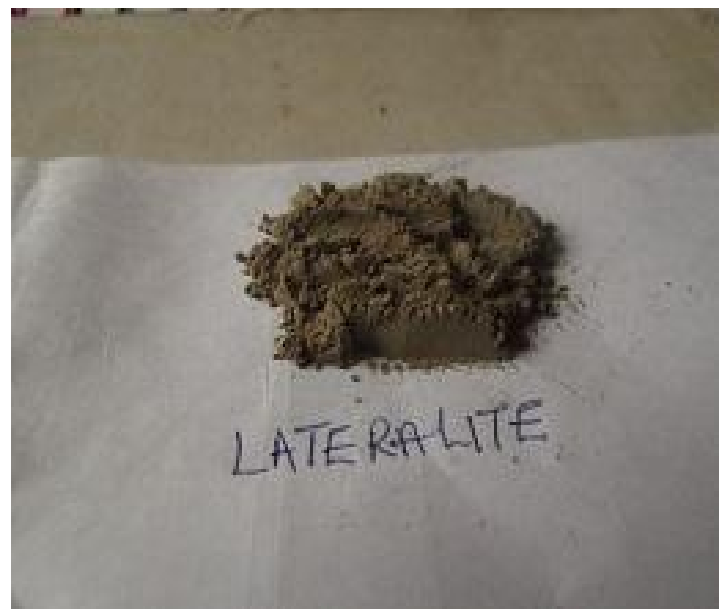

coarse particles (see Fig. 2). The unstabilised samples 1 and 2 had liquid limits less than $50 \%$ and the plasticity indices greater than 7 and were classified as CL soils in the USCS system, while in the AASHTO system the soils were classified as follows: sample 1-A-6 (clayey soil); sample 2A-2-6 (silty / clayey sand). Sample 3 was nonplastic and had less than $35 \%$ passing $63 \mu \mathrm{m}$ sieve, thus could be classified as ML in USCS and A-3 soil (fine sand) in the AASHTO classification system.

\subsection{Effect of Binders on Plasticity Index}

The plasticity index for Sample 1 was 25.7, sample 2 was 20.34, and sample 3 was nonplastic. With the addition of cement, there were reductions in the Plasticity Indices $(\mathrm{PI})$ with the lowest value obtained with $8 \%$ cement content for samples 1 and $2 \quad(4.66$ and 10.35 respectively), while an increase in plasticity was noticed in sample 3 with the highest PI (11.42) obtained with $6 \%$ cement content. However, $14 \%$ lateralite caused an increase in the plasticity of sample 1 and 3 (26.19 and 15.95 respectively) but a PI reduction in sample 2 (6.04).

Both cement and lateralite caused plasticity reduction in silty/clayey sand and made the nonplastic soil (the fine sand) to become plastic. They however had different effects on the clayey soil. While cement caused a reduction in the plasticity of the clayey soil, lateralite effected an increase (see Tables 2 and 3). The changes in the plasticity indices of the soils with variations in the cement and lateralite contents are shown graphically in Fig. 3.

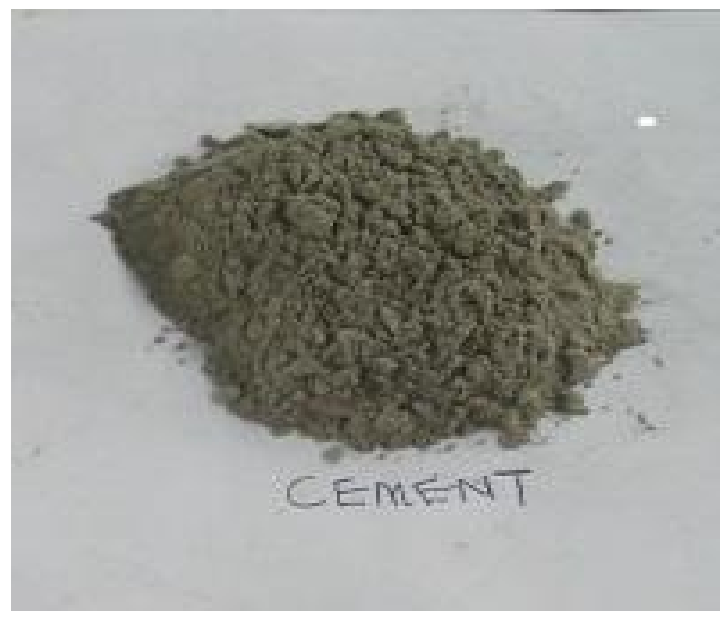

Fig. 1. Lateralite and cement 
Table 2. Results of soil analysis

\begin{tabular}{|c|c|c|c|c|c|c|c|c|c|c|c|c|c|c|c|c|c|c|}
\hline \multirow[t]{3}{*}{ Engineering properties } & \multicolumn{6}{|c|}{$\begin{array}{l}\text { East/West-Nyokuru link road } \\
\text { subgrade soil (1) }\end{array}$} & \multicolumn{6}{|c|}{$\begin{array}{l}\text { East/West-Nyokuru link road } \\
\text { borrow-pit soil (2) }\end{array}$} & \multicolumn{6}{|c|}{$\begin{array}{l}\text { Kaa-Ataba link road } \\
\text { subgrade soil (3) }\end{array}$} \\
\hline & \multicolumn{2}{|l|}{ Nat Soil } & \multicolumn{3}{|c|}{ Cement } & \multirow{2}{*}{$\begin{array}{l}\text { Later } \\
14 \%\end{array}$} & \multirow{2}{*}{$\begin{array}{l}\text { Nat Soil } \\
0 \%\end{array}$} & \multicolumn{4}{|c|}{ Cement } & \multirow{2}{*}{$\begin{array}{l}\text { Later } \\
14 \%\end{array}$} & \multirow{2}{*}{$\begin{array}{l}\text { Nat Soil } \\
0 \% \\
\end{array}$} & \multicolumn{4}{|c|}{ Cement } & \multirow{2}{*}{$\begin{array}{l}\text { Later } \\
14 \%\end{array}$} \\
\hline & $0 \%$ & $2 \%$ & $4 \%$ & $6 \%$ & $8 \%$ & & & $2 \%$ & $4 \%$ & $6 \%$ & $8 \%$ & & & $2 \%$ & $4 \%$ & $6 \%$ & $8 \%$ & \\
\hline AASHTO classification & $A-6$ & & & & & & A-2-6 & & & & & & $A-3$ & & & & & \\
\hline USCS classification & $\mathrm{CL}$ & & & & & & $\mathrm{CL}$ & & & & & & ML & & & & & \\
\hline NMC (\%) & 12.44 & & & & & & $0.80^{*}$ & & & & & & 27.86 & & & & & \\
\hline Specific Gravity & 2.53 & & & & & & 2.63 & & & & & & 2.48 & & & & & \\
\hline$\%$ Passing $63 \mu \mathrm{m}$ & 40 & - & - & - & - & - & 23.14 & - & - & - & - & - & 31 & - & - & - & - & - \\
\hline Liquid Limit (\%) & 32.58 & 24.51 & 28.63 & 25.91 & 24.21 & 47.12 & 37.82 & 34.28 & 33.04 & 39.04 & 36.78 & 34.58 & NP & 27.98 & 25.78 & 28.55 & 17.97 & 35.41 \\
\hline Plastic Limit (\%) & 6.88 & 14.35 & 13.35 & 14.98 & 19.55 & 20.93 & 17.48 & 11.89 & 9.73 & 20.28 & 26.43 & 28.54 & NP & 18.67 & 19.54 & 17.13 & 7.35 & 19.46 \\
\hline Plasticity Index & 25.70 & 10.16 & 15.28 & 10.93 & 4.66 & 26.19 & 20.34 & 22.39 & 23.31 & 18.76 & 10.35 & 6.04 & NP & 9.31 & 6.24 & 11.42 & 10.62 & 15.95 \\
\hline Linear Shrinkage Limit (\%) & 7.30 & 5.31 & 4.67 & 3.57 & 3.79 & 8.32 & 10.43 & 9.07 & 6.04 & 4.28 & 5.20 & 7.73 & 6.71 & 6.03 & 5.22 & 5.37 & 5.61 & 8.74 \\
\hline $\operatorname{MDD}\left(\mathrm{kg} / \mathrm{m}^{3}\right)$ & 2000 & 1970 & 1980 & 1980 & 1999 & 2065 & 1880 & 1935 & 2020 & 1970 & 1940 & 2070 & 2030 & 1970 & 1960 & 1950 & 2030 & 1972 \\
\hline OMC (\%) & 10.5 & 9 & 10 & 10 & 10.2 & 10 & 16.5 & 10.5 & 9 & 10 & 11.5 & 11.5 & 9 & 9.4 & 10.4 & 9.5 & 11 & 10 \\
\hline CBR $\%$ - Uns & 39.60 & 16.53 & 12.40 & 14.61 & 37.48 & 60.62 & 1.25 & 12.64 & 12.12 & 36.65 & 41.59 & 89.01 & 67.13 & 25.45 & 18.46 & 11.81 & 30.06 & 52.36 \\
\hline CBR \% - Soaked (24hrs) & 39.13 & 36.58 & 33.62 & 48.50 & 103.91 & 63.50 & 2.29 & 34.07 & 52.53 & 124.00 & 153.41 & 196.67 & 50.40 & 37.53 & 21.32 & 19.22 & 77.15 & 74.40 \\
\hline UCS (MPa) -7 days curing & 0.69 & 0.18 & 0.23 & 0.26 & 0.43 & 1.31 & 0.05 & 0.36 & 0.78 & 0.68 & 0.78 & 0.93 & 0.28 & 0.19 & 0.11 & 0.37 & 0.41 & 0.26 \\
\hline UCS $(\mathrm{MPa})-14$ days curing & 0.72 & 0.16 & 0.22 & 0.50 & 0.55 & 1.10 & 0.22 & 0.39 & 0.57 & 1.36 & 0.86 & 1.20 & 0.27 & 0.25 & 0.14 & 0.52 & 0.49 & 0.30 \\
\hline UCS $(\mathrm{MPa})-28$ days curing & 0.62 & 0.40 & 0.27 & 1.02 & 0.87 & 1.12 & 0.20 & 0.75 & 1.19 & 0.73 & 1.44 & 2.07 & 0.28 & 0.60 & 0.36 & 0.93 & 0.87 & 0.80 \\
\hline
\end{tabular}

Table 3. Summary of the effect of cement and lateralite on the soil samples

\begin{tabular}{|c|c|c|c|c|c|c|c|c|c|c|}
\hline \multirow[t]{2}{*}{ Soil and type } & \multicolumn{5}{|c|}{ Cement } & \multicolumn{5}{|c|}{ 14\% Lateralite } \\
\hline & PI & DD & CBR (U) & CBR (S) & UCS & $\mathbf{P I}$ & DD & CBR (U) & CBR (S) & UCS \\
\hline $\begin{array}{l}\text { Sample } 1 \text { (Clayey } \\
\text { soil) }\end{array}$ & $\begin{array}{l}\text { Lowest reduction at } \\
8 \%\end{array}$ & $\begin{array}{l}\text { Equal to natural soil at } \\
8 \%\end{array}$ & $\begin{array}{l}\text { Highest at } \\
0 \%\end{array}$ & $\begin{array}{l}\text { Highest at } \\
8 \%\end{array}$ & $\begin{array}{l}\text { Highest at } 6 \% 28 \text { days } \\
\text { curing }\end{array}$ & Increase & Increase & Increase & Increase & $\begin{array}{l}\text { Highest at } 7 \\
\text { days curing }\end{array}$ \\
\hline $\begin{array}{l}\text { Sample } 2 \\
\text { (Silty/Clayey Sand) }\end{array}$ & $\begin{array}{l}\text { Lowest reduction at } \\
8 \%\end{array}$ & Highest at $4 \%$ & $\begin{array}{l}\text { Highest at } \\
8 \%\end{array}$ & $\begin{array}{l}\text { Highest at } \\
8 \%\end{array}$ & $\begin{array}{l}\text { Highest at } 8 \% 28 \text { days } \\
\text { curing }\end{array}$ & Decrease & Increase & Increase & Increase & $\begin{array}{l}\text { Highest at } 28 \\
\text { days curing }\end{array}$ \\
\hline Sample 3 (Fine sand) & $\begin{array}{l}\text { Highest increase } \\
\text { at } 6 \%\end{array}$ & $\begin{array}{l}\text { Equal to Natural soil at } \\
8 \%\end{array}$ & $\begin{array}{l}\text { Highest at } \\
0 \%\end{array}$ & $\begin{array}{l}\text { Highest at } \\
8 \%\end{array}$ & $\begin{array}{l}\text { Highest at } 6 \% 28 \text { days } \\
\text { curing }\end{array}$ & Increase & Decrease & Increase & Increase & $\begin{array}{l}\text { Highest at } 28 \\
\text { days curing }\end{array}$ \\
\hline
\end{tabular}




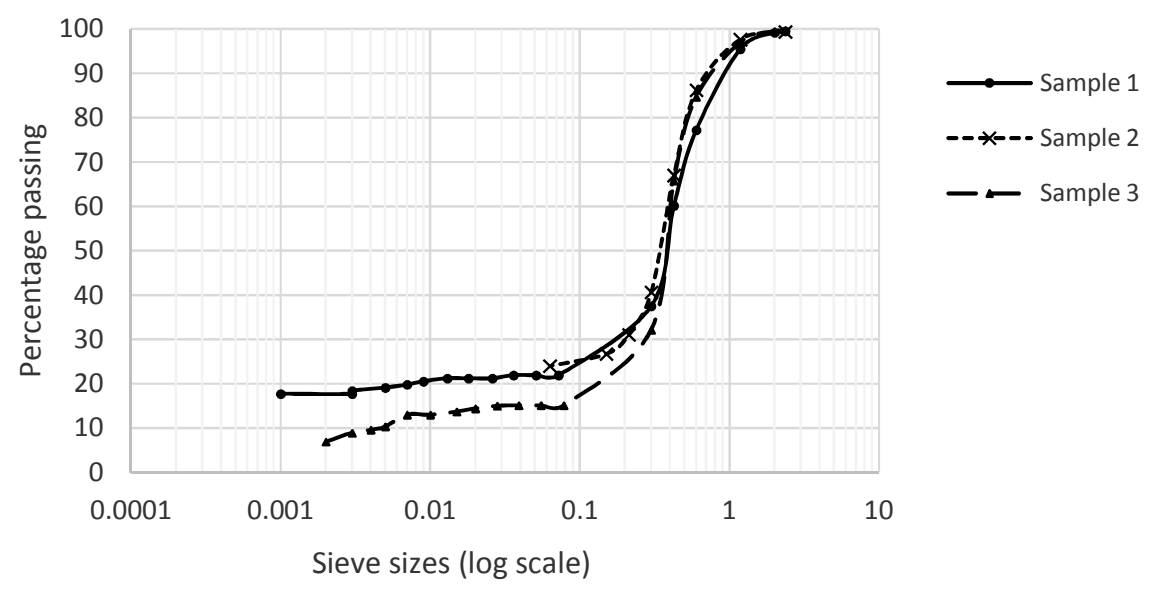

Fig. 2. Particle size distribution of Niger delta soils

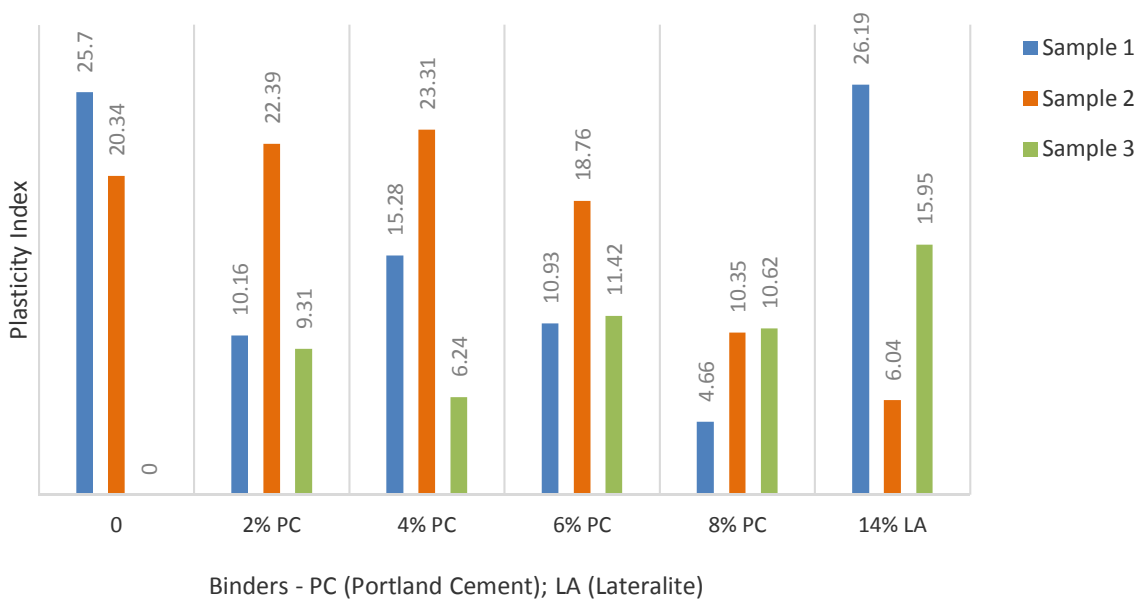

Fig. 3. Effect of binders on plasticity index

\subsection{Effect of Binders on Maximum Dry Density}

The compacted MDD of unstabilised sample 1 was $2000 \mathrm{~kg} / \mathrm{m}^{3}$ and there was a reduction with the addition of $2 \%$ cement, there was however a progressive increase as the cement content was increased and $8 \%$ cement content gave a dry density that was equal to the unstabilised soil MDD value. On the other hand, $14 \%$ lateralite had a marginal effect, achieving $2065 \mathrm{~kg} / \mathrm{m}^{3}$ MDD for the soil. The same trend was also observed with the cement stabilized sample 3 . The unstabilised soil had $2030 \mathrm{~kg} / \mathrm{m}^{3}$ MDD, and it had an equal MDD at $8 \%$ cement content, but $14 \%$ lateralite content reduced the MDD to 1972 $\mathrm{kg} / \mathrm{m}^{3}$. Unstabilised sample $2 \mathrm{MDD}$ was 1880 $\mathrm{kg} / \mathrm{m}^{3}$ and the highest impact with cement was obtained at $4 \%$ cement content $\left(2020 \mathrm{~kg} / \mathrm{m}^{3}\right)$, while $14 \%$ lateralite content gave $2070 \mathrm{~kg} / \mathrm{m}^{3}$ MDD. These effects on the soils are shown graphically in Fig. 4.

\subsection{Effect of Binders on CBR}

Unstabilised sample 1 had unsoaked CBR of $39.60 \%$ and 24 hrs soaked CBR of $39.13 \%$. Addition of cement caused a decrease in the unsoaked CBR, but which increased when soaked, and the highest unsoaked and soaked CBR were obtained with $8 \%$ cement content (37.48\% and $103.91 \%$ respectively), while $14 \%$ lateralite content gave $60.62 \%$ unsoaked CBR and $63.50 \%$ soaked CBR. 
Unstabilised sample 2 had very low unsoaked CBR of $1.25 \%$ and an increased soaked CBR of $2.29 \%$. Addition of cement effected a gradual increase in the unsoaked CBR which was further increased when soaked. But $8 \%$ cement content gave the highest unsoaked CBR of $41.59 \%$, and the soaked CBR of $153.41 \%$ respectively. For the same sample, Lateralite gave unsoaked and soaked CBR values of $89.01 \%$ and $196.67 \%$ respectively. In the case of the unstabilised sample 3, the unsoaked CBR value was $67.13 \%$, while a decreased value of $50.40 \%$ was obtained on soaking. $8 \%$ cement content gave an unsoaked CBR value of $30.06 \%$ and the highest soaked value of $77.15 \%$ for the sample.
Lateralite-stabilized sample 3 gave an unsoaked CBR of $52.36 \%$ and soaked CBR of $74.40 \%$. The effect of these binders on both the unsoaked and soaked CBR of the soils is graphically shown in Figs. 5 and 6.

From the analyzed CBR results, both cement and lateralite caused an increase in the CBR of all the samples especially when soaked in water. This showed that both binders need proper hydration which is beyond the optimum moisture content for the pozzolanic reaction that will yield more strength in the soils.

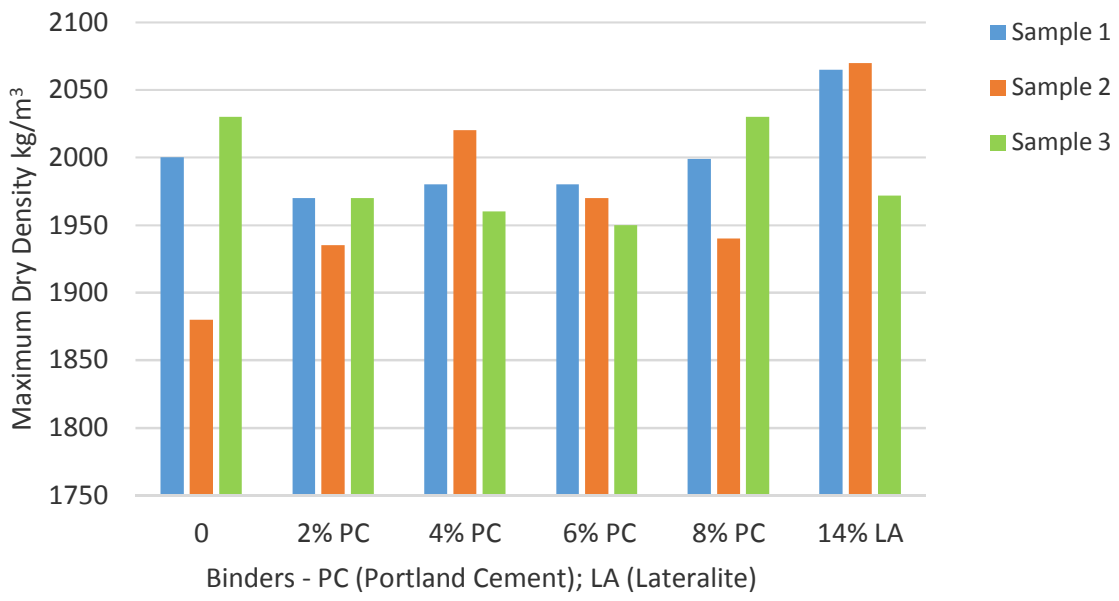

Fig. 4. Effect of binders on dry density

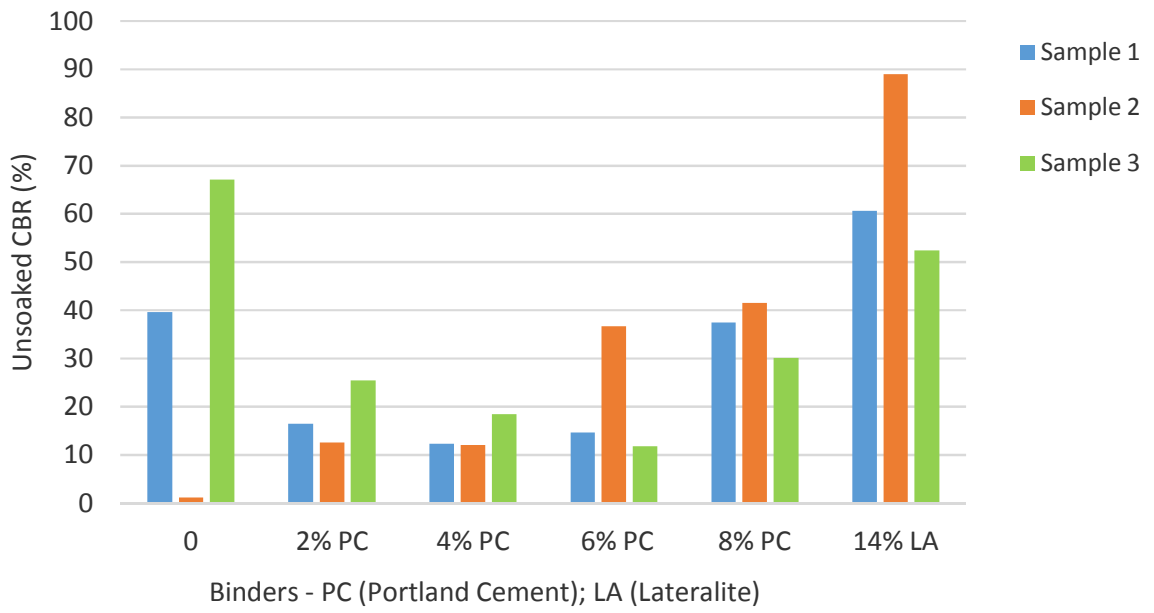

Fig. 5. Effect of binders on unsoaked CBR 


\subsection{Effect of Binders on UCS}

The unstabilised sample 1 had its highest UCS value of $0.72 \mathrm{MPa}$ at 14 days curing, its highest cement stabilized value of $1.02 \mathrm{MPa}$ at 28 days with $6 \%$ cement content, while $14 \%$ lateralite gave UCS value of $1.31 \mathrm{MPa}$ at 7 days curing. Unstabilised sample 2 had its highest UCS value of $0.22 \mathrm{MPa}$ at 14 days curing, the highest cement stabilized value of $1.44 \mathrm{MPa}$ at 28 days curing with $8 \%$ cement content, and $14 \%$ lateralite stabilized value was $2.07 \mathrm{MPa}$ at 14 days curing. Unstabilised sample 3 however had its highest UCS value of $0.28 \mathrm{MPa}$ at 7 days, $6 \%$ cement content yielded the highest value of 0.93 $\mathrm{MPa}$ at 28 days and $14 \%$ lateralite gave 0.80 $\mathrm{MPa}$ also at 28 days. The stability of sample 1 with the addition of $6 \%$ cement and $14 \%$ lateralite after the UCS test is shown in Fig. 7, and Figs. 8 - 10 showed the effect of the binders on all samples tested graphically.

The effect of both stabilizing agents on the soils' engineering properties is better summarized in Table 3.

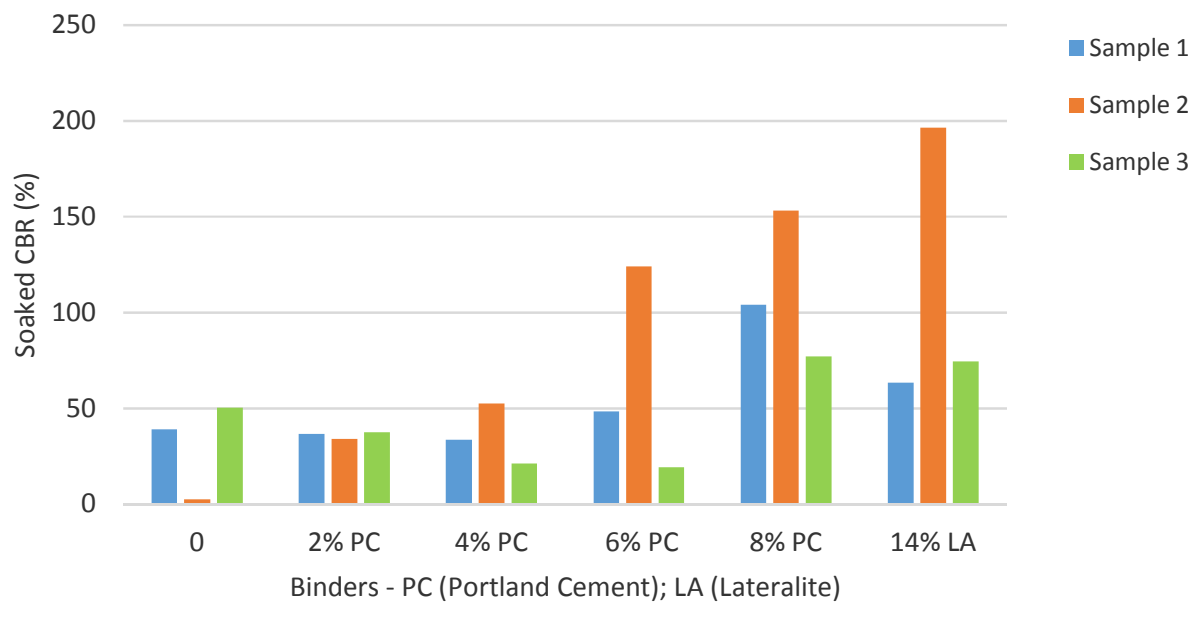

Fig. 6. Effect of binders on soaked CBR

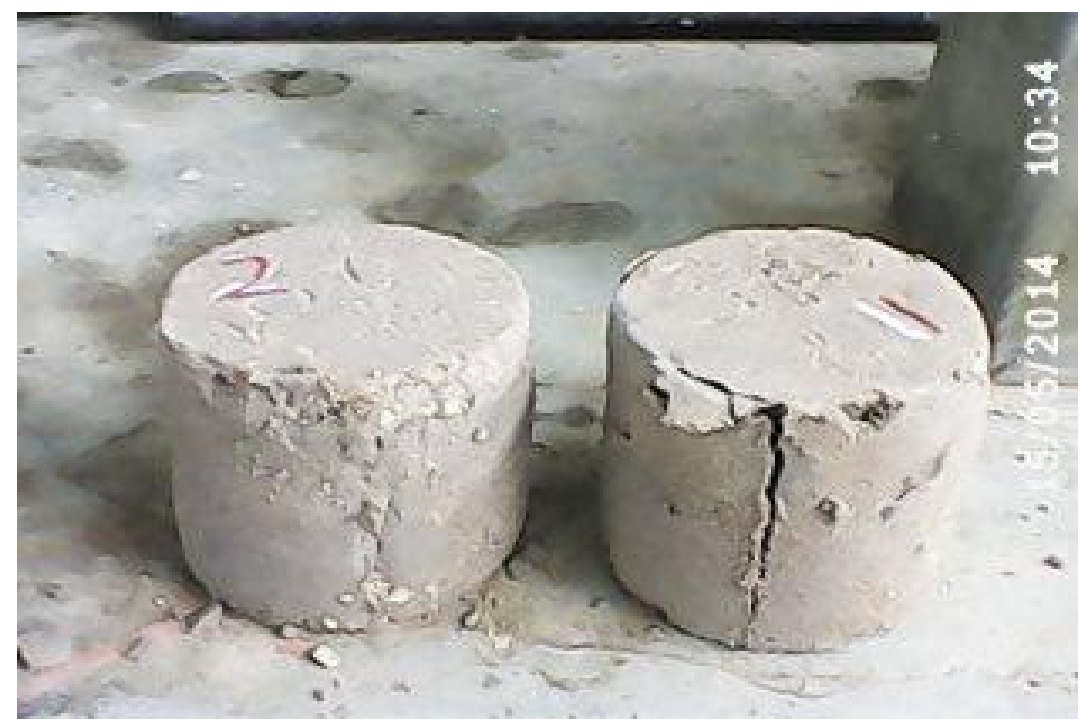

Fig. 7. UCS crushed sample 1: A - $14 \%$ lateralite content B - $6 \%$ cement content 


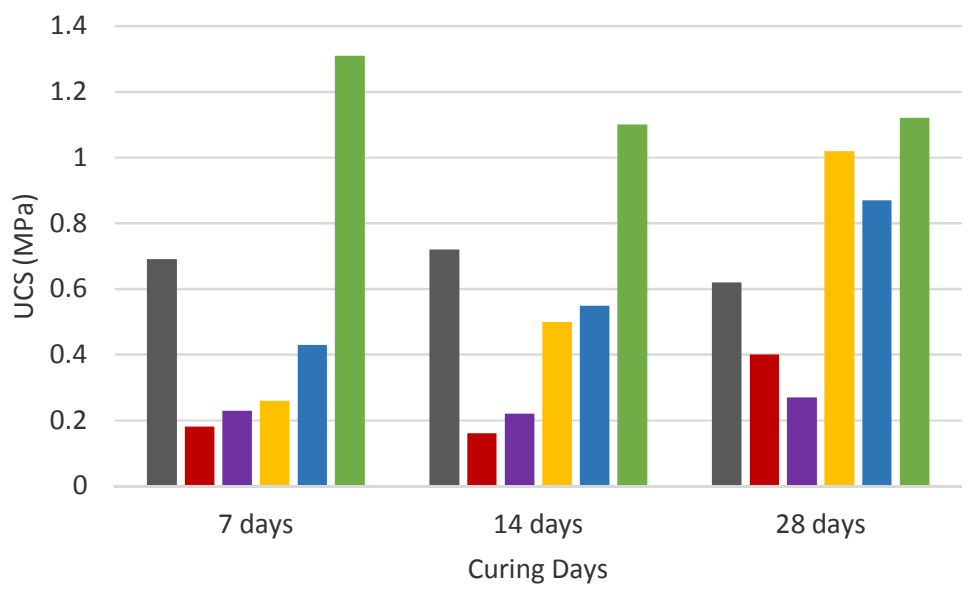

- UCS at $0 \%$

- UCS at $2 \% \mathrm{PC}$

- UCS at $4 \% \mathrm{PC}$

UCS at $6 \% \mathrm{PC}$

- UCS at $8 \% \mathrm{PC}$

- UCS at $14 \%$ LA

Fig. 8. Effect of binders on UCS for sample 1

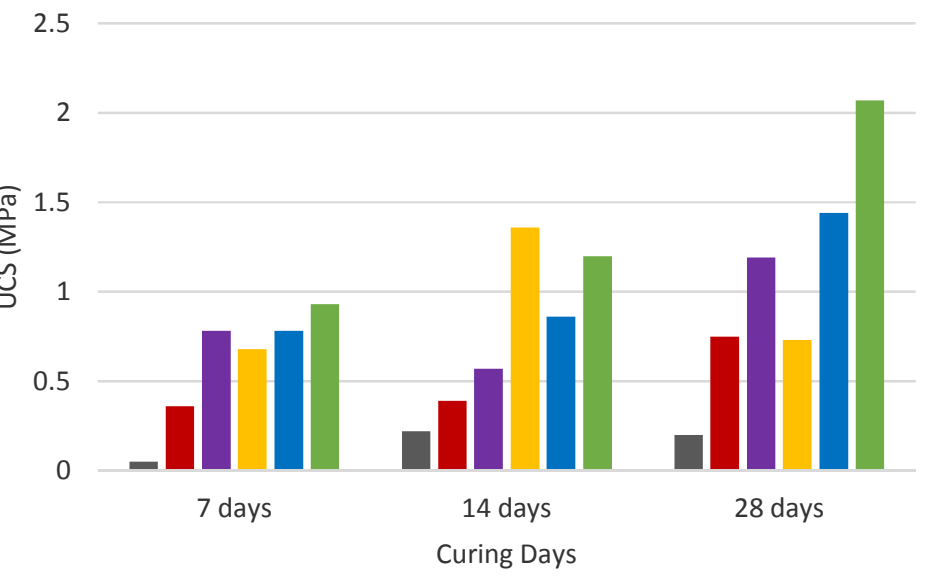

- UCS at $0 \%$

- UCS at $2 \%$ PC

-UCS at $4 \% \mathrm{PC}$

UCS at $6 \% \mathrm{PC}$

UCS at $8 \% \mathrm{PC}$

-UCS at $14 \%$ LA

Fig. 9. Effect of binders on UCS for sample 2

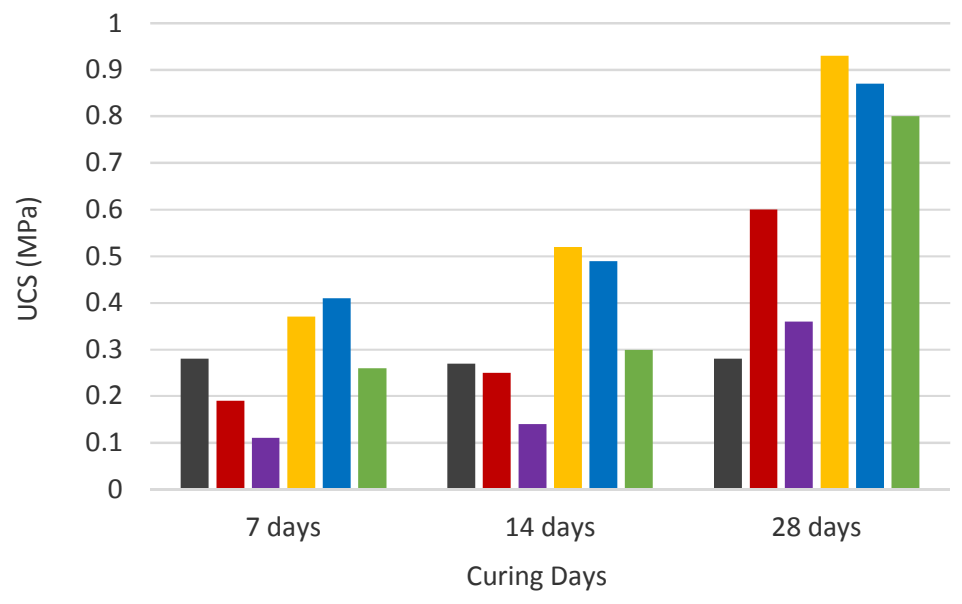

- UCS at $0 \%$

- UCS at $2 \% \mathrm{PC}$

UCS at $4 \% \mathrm{PC}$

- UCS at $6 \% \mathrm{PC}$

- UCS at $8 \% \mathrm{PC}$

- UCS at $14 \%$ LA

Fig. 10. Effect of binders on UCS for sample 3 


\section{CONCLUSION}

Portland cement had a better effect than lateralite on the clayey soil and fine sand in reducing the plasticity indices, increasing the dry density and gave a corresponding better effect on the soaked CBR and UCS at 28 days curing. However, lateralite worked better on the silty/clayey sand by effecting a reduction in the plasticity index, increased dry density and corresponding better effect on the soaked CBR and UCS also at 28 days curing. The silty/clayey sand showed the best response in terms of strength development with the application of both binders. The effect of moisture in aiding the pozzolanic reaction that will yield better bearing capacity was shown in the soaked CBR and the effect of long time curing that will yield higher shear strength was revealed in the UCS test. Although, the chemical analysis and the observed effect of lateralite on the study samples revealed that lateralite does not have the cementing capability of Portland cement, it however compared well to cement in affecting the engineering properties of the soils that will make them applicable as sub-base and base soils for pavement construction. Lateralite also exhibited the ability to remain stable in water, without losing its compacted strength, and without cracks, either when the treated samples remain dry (unsoaked), or when completely immersed/soaked in water for a long time. Hence it is recommended that further tests be carried out to understand lateralite stabilization mechanism.

\section{ACKNOWLEDGEMENTS}

The sponsorship of the PhD program of the first author by Schlumberger Faculty for the Future Foundation at the University of Cambridge, United Kingdom and the funding by CambridgeAfrica Alborada Scheme of this study which formed part of the PhD research are acknowledged.

\section{COMPETING INTERESTS}

Authors have declared that no competing interests exist.

\section{REFERENCES}

1. Al-Tabbaa A, Perera ASR. Part I: Binders and technologies - basic principles. In: Editors - Al- Tabbaa, A. and Stegemann,
JA. Proceedings of the International Conference on Stabilisation / Solidification Treatment and Remediation, University of Cambridge, United Kingdom. A. A. Balkema Publishers; 2005.

2. Al-Tabbaa A, Perera ASR. Part II: Binders and technologies - basic principles. In: Editors - Al- Tabbaa, A. and Stegemann, JA. Proceedings of the International Conference on Stabilisation/Solidification Treatment and Remediation, University of Cambridge, United Kingdom. A. A. Balkema Publishers; 2005.

3. Jegandan $S$, Liska $M$, Osman AA, AlTabbaa A. Sustainable binders for soil stabilisation. Proceedings of the Institution of Civil Engineers: Ground Improvement. 2010;163:53-61. ISSN 1755 - 0750.

4. Akpokodje EGA. Method of reducing the cement content of two stabilized Niger Delta soils. Quarterly Journal of Engineering Geology, London. 1986;19: 359-363.

5. Eze EO, Suoware OP. Geotechnical evaluation of untreated and cement-treated Ajali sandstone from southeastern Nigeria. Quarterly Journal of Engrg. Geol. 1993;26: 137-148.

6. Omotosho O. Influence of geosta addition on cement-stabilized chicoco mud of Niger Delta. American Jour. of Environ. Sciences. 2005;1(1):59-63.

7. Omotosho O, Eze-Uzomaka OJ. Optimal stabilization of Deltaic Laterite. Institution of Civil Engineering, Technical Paper. 2008;50(2):10-17.

8. Omotosho O, Ogboin AS. Active soils of Niger Delta in road pavement design and construction. Geotechnical and Geology Engineering. 2009;27:81-88.

9. Sridharan A, Rao AS, Sivapullaiah PY, Swelling pressure of clay. Geotechnical Test J. ASTM. 1986;9(1):24-33.

10. Federal ministry of works and housing. General Specification- Roads and Bridges. 1997;2:280. Director of Federal Highways, FMWH, Abuja, Nigeria.

11. Joel M, Agbede IO. Mechanical-cement stabilisation of Laterite for Use as flexible pavement material. Journal of Materials in Civil Engineering, ASCE. 2011;146-152. Assessed from ascelibrary.org by Cambridge University on 08/13/12.

12. Alayaki FM. An examination of the engineering characteristics of lime, cement and terralite stabilized laterite base courses. M.Sc. Thesis, Dept. of Civil 
Engineering, University of Lagos, Nigeria 2001. (Unpublished).

13. Meshida EA, Alayaki FM, Akanbi EO. A comparative study of portland cement, hydrated lime and lateralite as stabilizing agents of quaternary coastal plain sands north of Lagos Metropolis as road construction material. Africa Geoscience Review, Rock View Ltd, France. 2011; 18(4):137-142.

14. British Standards 1377. British Standard Methods of test for Soils for Civil Engineering Purpose. British Standards Institution, London; 1990.

15. AASHTO T 131-06: Standard Method of Test for Time of Setting of Hydraulic Cement by Vicat Needle. American
Association of State Highway and Transportation Officials; 2006.

16. British Standards 1924. Stabilized Materials for Civil Engineering Purposes Parts 1 and 2. British Standards Institution; 1990. ISBN 058018497.

17. BS EN 197-1. Cement - Part 1: Composition, Specifications and Conformity Criteria for Common Cements; 2000. BSI 9 July 2004, ISBN 058036456 9.

18. Kosmatka SH, Kerkhoff B, Panarese WC. Design and control of concrete mixtures. Portland cement Association, ASM Handbook Volume 13B, November; 2005. Skokie, IL. 14 ${ }^{\text {th }}$ Ed., 2002.

(c) 2015 Alayaki et al.; This is an Open Access article distributed under the terms of the Creative Commons Attribution License (http://creativecommons.org/licenses/by/4.0), which permits unrestricted use, distribution, and reproduction in any medium, provided the original work is properly cited.

Peer-review history:

The peer review history for this paper can be accessed here: http://www. sciencedomain.org/review-history.php?iid=1137\&id=5\&aid=9224 